（5）オールスキンに近いSuper 型コードの左山，右山の高 さはコアのあるコードに比較して左右山ともに著しく高く, ラテ ラルオーダー的には均一であると考えられ，ラテラルオーダーの 低い領域量も多い。また上記試験機による疲学强度試験結果もす ぐれており，かっそれからつくったタイヤは実用上優良であると いわれている。一方, 左右山の高さが最も低く, ラテラルオーダ 一分布の不均一なコードの上記試験機による疲労強度試験結果は 不良であり，かつそれからつくったタイヤの実際走行試験結果は
最も不良であることが確認されている。以上の結果からいわゆる ラテラルオーダー分布と実際走行試験結果との関係を推定した。

(本研究は昭和 31 年 4 月 3 日, 日化第 9 年会, および同年 6 月 3 日瀻維学会で講演)

本研究にあたり試料をいたたいた横浜ゴム製造 K K 研究部長小 出武城氏および帝国人絹 $\mathrm{K} \mathrm{K}$ 前田薑氏に梁謝し，また平行度試験 をしていたたいた東洋レーヨンK K 研究所長星野孝平氏に感謝の 意を表する。

\title{
$\mathbf{X}$ 線分析によるセルロースの微細構造, ことに結晶化に関する研究
}

(昭 和 31 年 7 月 28 日 受理)

\author{
祖父江 寛・湊宏 ${ }^{*}$
}

\section{I. 酸加水分解初期における結晶化}

緉維素の結晶領域定量の化学的方法として, 酸による加水分解 法が多くの研究者によって研究され，操作が簡単であり，かつ， 相対的目安をらるに便なるため, 普通よく行われているけれど る，その加水分解初期に結晶化が起ることが, Ingersoll1) Hermans $^{2)}, \mathrm{Mark}^{3)}$ らによって指摘された。しかしこの問題に対す る解明は未だ十分になされてはいない。著者らはX線法により酸 加水分解初期に起る, この結晶化について研究した。

\section{実}

試料として強力人絧を用い，これをガラス枠に平行に均一に卷 きつけ，これを $1.5 \mathrm{~N}-\mathrm{HCl}$ 水溶液に $95^{\circ} \mathrm{C} て ゙ 3$ 分, 5 分, 8 分 および 11 分浸して非結晶領域を溶解させ漸次結晶領域にとむる のとしたのち，計数管付きX線回折装置を用いてその赤道線上の 干渉図をえた。これを第 1 図に示す。
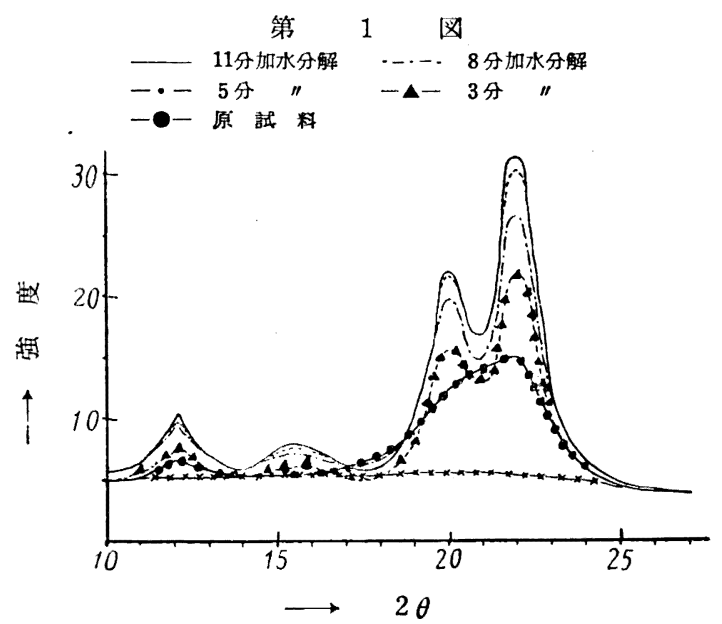

\section{考察}

第 1 図から明らかなよ5に，酸加水分解初期に著しい結晶化が

* 東京大学工学部応用化学科：東京都文京区本富士町.

1) H. G. Ingersoll, J. Applied Phys. 17, 924 (1946).

2) P.H. Hermans, A. Weidinger, ' . Polymer Sci. 4, 317 (1949)

3) F.C. Brenner, V.J. Frilette, H. Mark, J. Am. Chem. Soc. 70, 877 (1948).
起ることが示され ている。002, $10 \overline{1}$, のピークの 高さが增すととも に，それぞれの山 が鋭くなってわか れてくることが見 られる※。第1図 において，結晶部 分による干渉と思 われる部分の面積 a. および 002 の

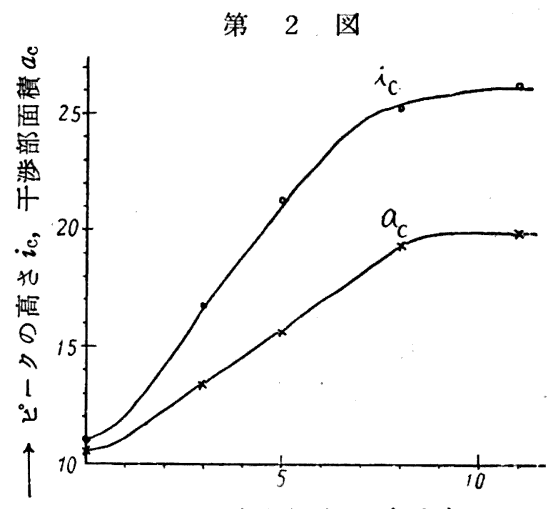
$\longrightarrow$ 加水分解時間 $(\mathrm{min})$ ピークの高さi:で便宜的にその結晶化の過程を示すと第 1 表损 よび第2罒のと拈りである。

\begin{tabular}{cccccc} 
& \multicolumn{3}{c}{ 第. } & 1 & 表 \\
& & & & & \\
& & 3 & 5 & 8 & 11 \\
\hline$a_{\mathrm{c}}$ & 10.5 & 13.3 & 15.7 & 19.4 & 19.9 \\
$i$. & 11.0 & 16.8 & 21.4 & 25.4 & 26.2
\end{tabular}

これらから見ると，酸加水分解初期の結晶化は, $1.5 \mathrm{~N}-\mathrm{HCl}$, $95^{\circ} \mathrm{C}$ で約 8〜11 分ぐらいで完結するものと思われる。

$\mathrm{X}$ 線干渉図のピークの幅は，結晶粒子のこまかさおよび格子攪 乱によるものと考えられるから，このよ5に 002, 101 などの ピークが鋭くなり互いに分離したことは，（1）結晶粒子の幅が 大きくなったか，（2）従来存在していた格子の歪みが是正され， 歪从が咸少したか，のいずれか，またはその両方によるるとして 説明でさる。しかし，そのいずれによるかは，この図からだけで は判断できない。そこで今この人絹を $3 \mathrm{~N}-\mathrm{HCl} 100^{\circ} \mathrm{C} て ゙ 15$ 分 加水分解し水洗したのち，8\% カセイソーダ水溶液にとかし口過 し，口液に塩酸を加えて緎維素を沈殿として再生させ，これを遠 心分離により洗净，乾燥させ，粉末状絨維素をうる。これはその 生成過程から見て結晶粒子は小さく，また格子の乘みはほとんど

※ 非干涉散乱による補正扰よび非結晶部分の干涉の補正をし て第 1 図に示したような-.-.X.-.・X-.-・可線などをえ たとすると，結晶部分の干渉に基く面積 $a_{\mathrm{c}}$ およびそのピ 一クの高さ $i_{\mathrm{e}}$ が求められる。な扰 $a_{\mathrm{c}}$ はプラニメーター で求めた。 
ないものと思われ る。このX線干渉図 を第 3 図に示す。 この図で 002 と $10 \overline{1}$ の二つの山を計 算によって分離し, 002 について半価幅 を求める。また 1.5 $\mathrm{N}-\mathrm{HCl} 95^{\circ} \mathrm{C}$ で, ガ ラス枠に巻き繊維状 で 11 分加水分解し たものを軽く乳鉢で

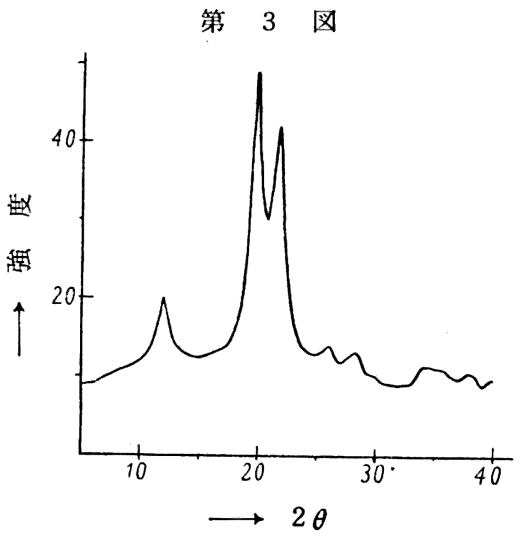

粉にして粉末 X線図を5る。これから 002 の半価幅を求めると後 者の方がやや大きい值を示す。後者にはまだ格子の枉みが残存し ているであろうことを考えに入れると, 両者の半価幅は大体同じ くらいであると思われ，したがって，加水分解初期に起る結晶化 に扒いてこの試料の絬晶粒子の幅が增したとは認め難い。この 結晶化は, 格子歪みの是正という形でなされたものと推定され る。そして,このことはまた, 全然無配列の非結晶部分が配列し て新しい結晶部分を生むことよりは, 結晶部分の歪みの是正, す なわち中間領域の規則性向上による結晶化の方がより起り易い之 考えることからも理解できることである。

レーヨンのX線図は, 一般に 002 と $10 \overline{1}$ が互いに重なり合っ て両ピークの間の谷はほとんど認めることができない。これは， ほとんどその格子の乱れによるものと思われる。そらして，これ らの乱れは加水分解初期に, 結合部分が切れたことにより回転の 自由をえて配列し，この結果，X線図のピークが鋭くなったので あろら。

後に，II章第 4 図に示すよ5に，ミラーは酸加水分解に打いて も汇とんど結晶化が見られない。Hermans ${ }^{4}$ もこのことを指摘 しており，彼はラミーの非結晶部分はレーヨンのそれと異なった 性質のものであろうといっているが，これは中間領域と考えられ る部分の羑として明快に説明されうることで, レーヨンの結晶部 分は非常に乱れて拈り, 加水分解初期にその部分が配列して結晶 化度を向上させるのに対し，ラミーでは格子の歪み少なく，すな わち中間領域がほとんどなく，そのような条件に置かれても結晶 化は起らないか，またはごく少ないのであると考えられる。

このように格子歪みの多いレーヨンなどの結晶化度决定のため に酸加水分解法を用いると, その中間領域の結晶化のために高度 結晶領域と中間領域の和をらることになる。したがって反応中に 試料の結晶化が起らない結晶化度定量法, 寸なわち, Mark ら の重水置換法5), Timell の液体アンモニア法6), Rosevear の酸 化加水分解法 ${ }^{7}$, Hermans $5 の X$ 線法8), Tarkow, Nickerson らのギ酸エステル法9,10) などによってえた結晶領域量と, 初期に

4) P.H. Hermans, A. Weidinger, J. Polymer Sci. 4, 317 (1949).

5) V.J. Frilette, J. Hanle, H. Hark, J. Am. Chem. Soc. 70, 1107 (1948).

6) T. Timell, Dissertation, Royal Institute of Technology, Stockholm (1950).

7) W.E. Roseveare, Ind Eng. Chem. 44, 168 (1952).

8) P.H. Hermans, A. Weidinger, J. Applied Phys. 19, 491 (1948).
結晶化の起る通常の酸加水分解法によってえた結晶領域量の差と して中間領域が示されると考えてもよかろう。Hermans らは酸 加水分解法では再結晶化が起るため, 結晶化度決定のためには加 水分解法は不適当であると結論したが，これは，今述べたような 意味に拀いて，他の方法によるデータと総合して結晶化状態を説 明するに必須のものと考える。

著者らの強力人絹に関してえた値についてみると, 第 1 表に示 したよ5に結晶領域と考えられる部分が，未処理試料 10.5, 初 期結晶化終了後の試料については 19.9 と約 2 倍になっている。 すなわち, 大体高結晶化度部分と等量ぐらいの中間領域部分がこ の強力人絹には存在すると考号れるが，これは強力人綟につい て Hermans ${ }^{8)}$ らがX線法でえた結晶化度 $39 \%$ と，酸加水分解 法によってえた Nickerson ら ${ }^{11)}$ の 79\%, Conrad ら ${ }^{12)}$ の 69〜 $73 \%$, Phillip ら ${ }^{13)}$ の $62 \%$ の差が中間領域であると解釈寸れば, 大体一致した值である。

\section{II. 各種織維の酸加水分解初期における結晶化}

I に括いて, 繊維素䋐維の酸加水分解初期に起る絬晶化は, 格 子歪みを有する不完全結晶部分，すなわち，中間領域の規則性向 上によるものであると説明したが，これに基き種々の㵶維の短い 加水分解による結晶化の状態を観察して, それらの緎維の微細構 造に関する知見をえようと試みた。

\section{実験}

ラミー, マーセル化ラミー, ピスコース普通人絹, 強力人絹 (1), 強力人絹 (2), ベンベルグの 6 種の試料をI と同様にガ ラス枠に巻付计て, $1.5 \mathrm{~N}-\mathrm{HCl}$ 水溶液で $95^{\circ} \mathrm{C}, 5$ 分間加水分解 し, 水洗, 真空中で乾燥したのち, 計数管付き $\mathrm{X}$ 線回折装置で赤 道線上の干渉図をえた。それらを第 4 図に示す。

\section{考䀂}

ラミーとベンベルグは, 加水分解の前後でほとんど変化がな い。ラミーでは僅かに結晶化度が減少しているもののようであ 第 4 図 $(1 \sim 2)$

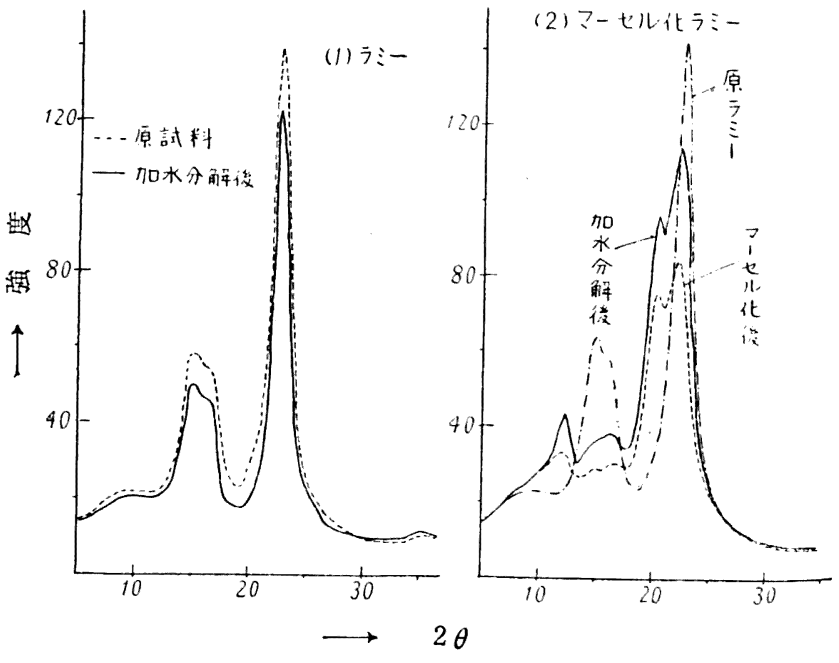

9) H. Tarkow, Tappi 33, 595 (1950).

10) R.F. Nickerson, Textile Research J. 20, 549 (1950).

11) R.F. Nickerson, Ind. Eng. Chem. 39, 1507 (1947).

12) C. C. Conrad, A.G. Scroggie, ibid. 37, 592 (1945).

13) H.J. Phillip, M. L. Nelson, H.M. Ziifle, Textile Research J. 17, 585 (1947). 

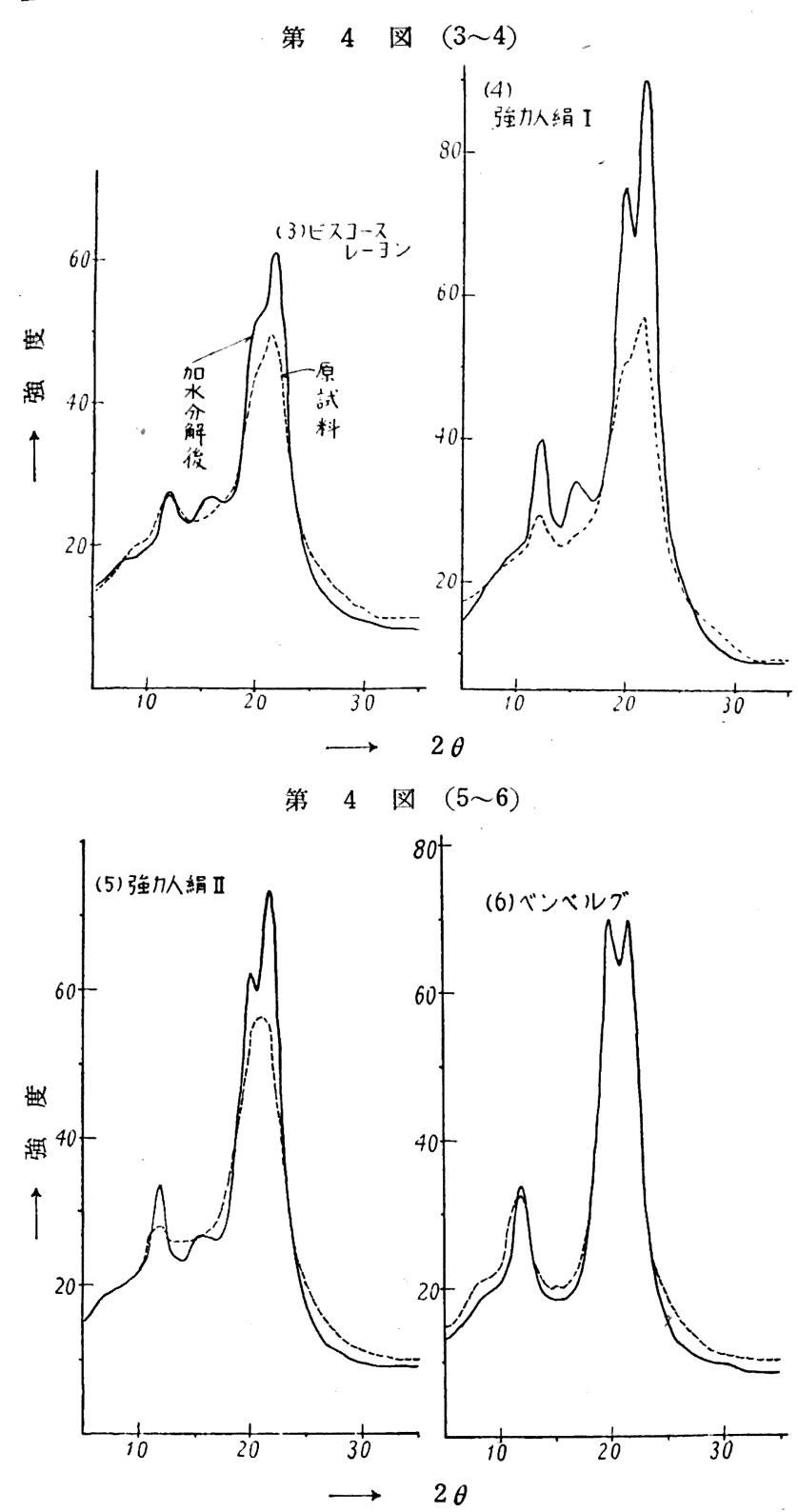

る。それら以外のマーセル化ラミー, 普通人絹, 强力人絹 $(1)$, 強力人絹 (2) では, いずれも著しく結晶化を起したことが見ら れる。すなわち， 3 種のビスコース人絹は, いずれも未処理の状 態では不完全結晶部分が多く存在しており，002，10푸 のピーク が互いに重なり合っていたのが，酸加水分解により結晶化して各 ピークがわかれ，また著しく強度を増している。また，101，101 の中間に今まで, 相互の重なり合いによって隠されていた小さい

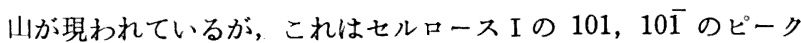
であろうと考えられる（このことについては，IIIで詳述する）。

ビスコース人絹 3 種の中では, 強力人絹の方が普通人絹よりも 結晶化の程度が著しい。ラミーでは結晶化が起らないのにマーセ ル化ラミーで結晶化が起るのは, マーセルによりセルロース I か らセルロースIIに転移する際に, 完全な転移が行われずに, 格子 内に歪又を持つ不完全な結晶がかなり多く存在しており,この部 分がレーヨンの場合と同様に加水分解によって回転の自由をえて 結晶化したものと思われる。ラミーとベンベルグでは結晶化がほ とんど見られないことから，これらの絨維には格子の乱れた中間
第 5 図

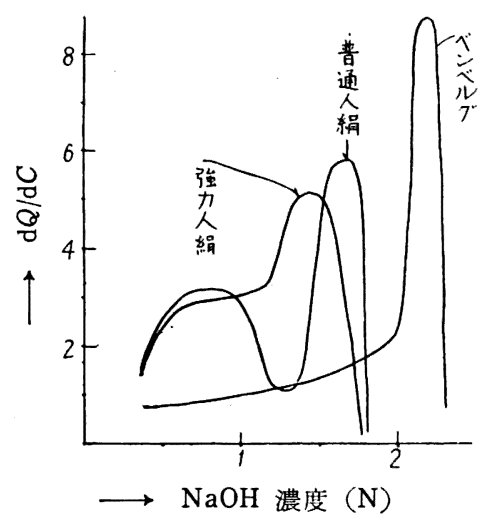

領域がほとんど存在せ ず，結晶領域と非結晶領 域が, 比較的判然たる区 別を有し，高度に結晶し た絬晶領域とほとんど無 配列の非結晶領域とから なるものと考えられる。 ラミーが, 逆にやや結晶 化度を減じたのは, 膨 潤, 脱膨潤の過程におい て格子の乱れが起ったも のであろ5。

万木, 前田らのアルカ
リ可溶度によるラテラルオーダー測定法により, ベンベルグ, 普 通人絹, 強力人絹1) の 3 種の纎維のラテラルオーダ分布を求め第 5 因に示寸。これに打いても，X線図の場合と同様なベンベルグ とビスコース人絹との差が見られる。

\section{III. 酸加水分解，およびカセインーダ処理による 緎維の微細構造の变化}

緎維素瀻維の微細構造解明の一手段として, 酸加水分解, およ びカセイソーダ処理による微細構造の変化を, X線干渉図の変化 から研究した。

\section{実験}

強力人絹系を $6 \mathrm{~N}-\mathrm{HCl}$ 水溶液で $100^{\circ} \mathrm{C}$ にて $10,30,90,150$ 分間それぞれ加水分解し, その残留物を水洗, 乾燥したのち, 軽 く乳鉢ですりつぶして粉末として計数管付きX線回折装置により $\mathrm{X}$ 線干渉図をえた。また同一試料を万木, 前田らのアルカリ可溶 度によるラテラルオーダー分布測定の方法にしたがって，3.5 N-

\section{第 6 図 $\quad(1 \sim 2)$}
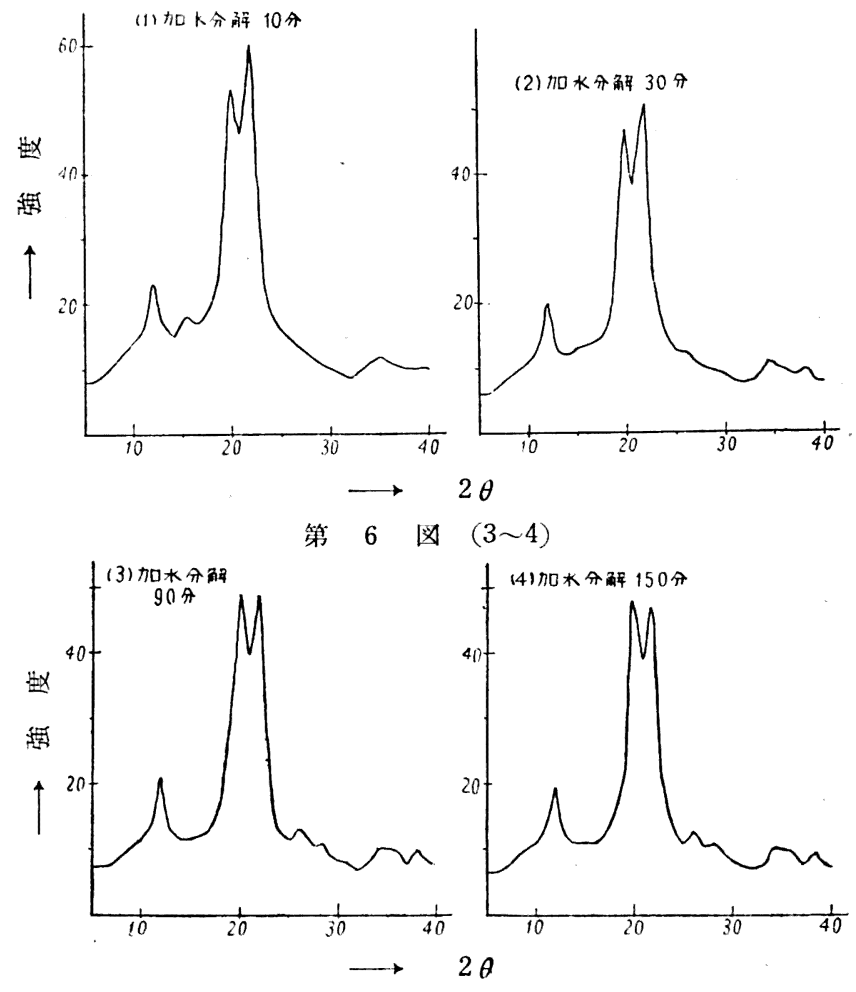


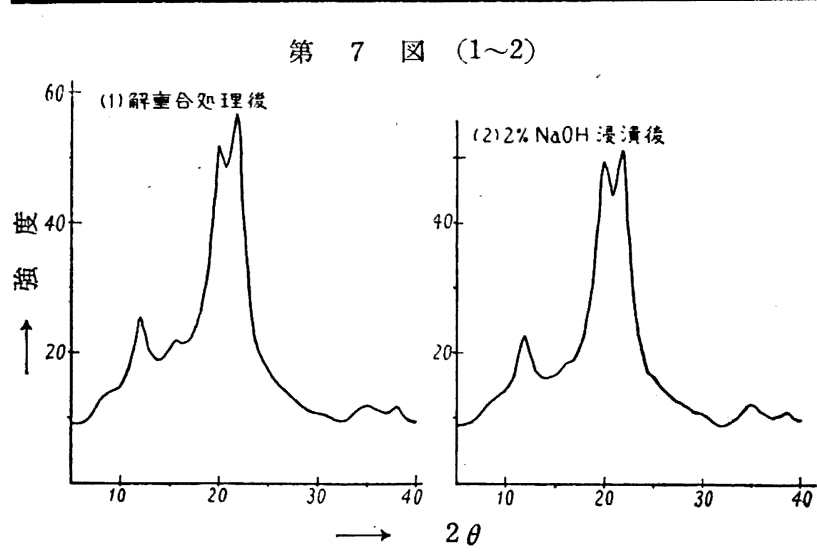

第 7 図 $(3 \sim 4)$

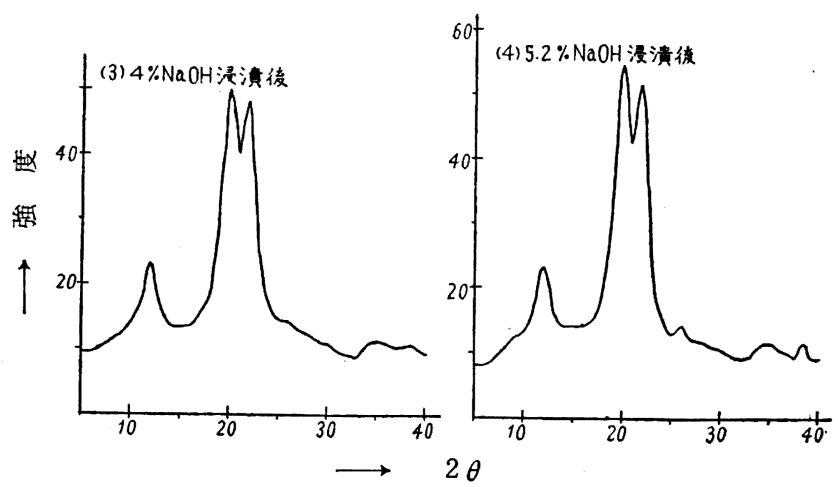

$\mathrm{HCl} 5$ 容, エタノール 95 容の塩酸アルコール溶液で $80^{\circ} \mathrm{C}$ にお いて㵶維を 6 時間予備解重合し水洗したのち 2, 4, 5.2\% カセ イソーダ溶液に $20^{\circ} \mathrm{C}$ で 30 分浸漬して水洗， $5 \%$ 酢酸で洗い再 び水洗, 乾燥, 粉末としてこれを加水分解の場合と同様にしてX 線干涉図をえた※1。それらを第 6,7 図に示した。

第 6 図において, 加水分解 10 分にしてすでに少量の非晶部分 の溶失および初期結晶化の両効果によって，002，10 $\overline{1}$ の両ピー クが少しわかれており，また $2 \theta$ の大きい部分における弱いいく つかの山も，同様に結晶化によって重なり合いが除かれて見るこ とができるようになっている。しかしここで最も興味あることは 加水分解 10 分の試料に打いて $15 \sim 16^{\circ}$ に見られる小さな山が, 加水分解の進行とともに徐々に消失していること, および同様に 加水分解の進行とともに 002 が低く, $10 \overline{1}$ が高くなり, 加水分 解 150 分では逆に $10 \overline{1}$ の方が 002 より高くなっていることであ る。この $15 \sim 16^{\circ}$ に見られる小さな山は前にII章第 4 図で示した よ5に, 赤道線上の干渉であり, これはこのレーヨン中に混在す るセルロースIの 101，101 のピークであるとして最もよく説明 される※2。すなわちこのレーヨンの結晶粒子のある少数のものは セルロース I の結晶構造を有し，このため $15 〜 16^{\circ}$ に 101，10 の弱いピークを生じ，また $20^{\circ}$ に拈けるセルロースIの $10 \overline{1}$ の付 近には何も生じないから，したがってこのピークは低く出てお。 り，22.5 に拈いてセルロースIの002 の干渉を生ずるが，これ は $22^{\circ}$ におけるセルロースII強い002のピークと重なり合って はっきり区別はできないが，七ルロースIIの 002 のピークを強 め, またその半価幅を增している。加水分解が進むにつれて, こ のセルロースIの結晶粒子も他の多くのセルロースII の結晶粒子

$※ 1$ 祖父江, 福原, 繊維学会昭和 31 年 6 月講演会発表.

$※ 2$ 詳細後報 (工化誌投稿).
とともに分解され溶失していく。大体， 1 時間から 2 時間加水分 解することによりセルロースI は汇とんど分解し去るすののよう である。すなわち 101，10̄̄ の小さい山は消え002 は徐々にその 強さを減じ $10 \overline{1}$ は増加している。この試料を $3 \mathrm{~N}-\mathrm{HCl} て ゙ ~ 100{ }^{\circ} \mathrm{C}$ で 15 分加水分解し， $8 \%$ カセイソーダ水溶液に溶解，口過し， 口液に塩酸を加え沈殿再生させた粉末試料のX線図（第 3 図）と 比較してみる。このようにしてえたるのはセルロースIIだけから なる。よく発達したこまかい結晶粒子を含むと考えられるが，こ の図では $10 \overline{1}$ が 002 より高く出ている。すなわち完全にセル口 ースIIたけからなる陚料のX線図においては $10 \overline{1}$ の方が 002 よ りも強いピークであると思われる。したがって $6 \mathrm{~N}-\mathrm{HCl} て ゙ 2$ 時 間半加水分解した試料でもほとんどのセルロース I は溶失し去っ たけれども，まだ僅かのセルロースIが残存しているるのと思わ れる。セルロースIIの干沙強度に関し綿密な計算を行った Andress ${ }^{14)}$ が， 002 に対し 180，10̄ に対し 240 の値をえているが, これは粉末再生人綟に関して大体一致する。

第 7 図のアルカリ可溶度によるラテラルオーダーの異なる 4 種 の試料についてのX線図から次のよ5なことがわかる。すなわち 塩酸アルコール溶液による解重合に打いては塩酸水溶液によるほ ぞ過激ではないが，僅かに中間領域の結晶化が起って 002, $10 \overline{1}$ の両ピークが少しわかれてくる。そして，この試料をアルカリに

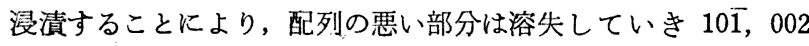
のピークが徐々に分離してくる。解重合のみのものでは 15 16 に拈いて，七ルロースIの 101，101 が認められ，これは順次に 高濃度のアルカリに浸漬することによって溶失し去っていくこと が見られる。そしてそのことは 002 のピークが徐々にその高さを 減じ，10̄̄̄が徐々に高さを增して，4\%，5.2\%アルカリに浸漬し たものでは 101 の方が高くなっていることによっても支持される ことである。

このよ5に、レーヨン中に存在するセルロースIの結晶粒子 は, 解重合, アルカリ処理により比較的とけ易く, 格子の乱れた 小さい粒子であろうと思われる。このことはまた，加水分解にお いて割に早い時期に大部分のセルロースIが溶失したことからも らかがわれることである。しかし加水分解执よびアルカリ浸漬に よっては,アルカリ溶解後沈殿再生した試料（第3図）に拈ける ような $10 \overline{1}$ と 002 の差がえられないことから、いくらかのセル ロース I は結晶粒子の内部に存在, 寸なわち外側をセルロース II で囲まれたような形で存在するものであろう。

以上のように, ある種の再生繊維素䋐維ではセルロース I の結 晶構造を持つ結晶粒子が少量残存していることが確かめられた が、このことについて，すでに示した未処理および僅かに加水分 解した各再生㵶維素絨維のX線図（第 4 図）をその意味から眺め てみる。普通人䋧, 強力人綟 (1), 強力人絹 (2) の三つの試

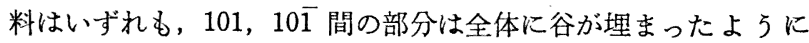

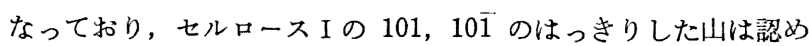
られないけれども，これは格子の乱れた不完全結晶部分を多く有 するための重なり合いによるもので， 5 分の加水分解によって中 間領域が結晶化し重なり合いが除かれた図では 3 試料ともに，は っきりしたセルロースIの 101，101 のピークが認められる。そ してその干渉図は不完全マーセル化ラミーの干逤図とほとんど同 じような形状である。ベンベルグに拈いては $101 ， 10 \overline{1}$ 間が大き

14) K. R. Andress, Z. phys. Chem. B 2, 380 (1929). 
く谷となっており，セルロースIは存在しないるのと思われる。 そしてこれらのことは,ベンベルグにおいては $10 \overrightarrow{1} と 002$ がほ とんど同じ高さであるのに対し，ビスュース法人絹では 002 が $10 \overline{1}$ よりずっと高くでていることからも支持せられる。

従来ビスコースの分散状態に関し，分子分散なりとする説と， ミセル分散なりとする説とが対立していたが，上記の結果は，工 業的な人絹用ビスコース I の製造条件ではセルロースIの格子を 持つミセル分散のものが存在しうることを示している。

\section{IV. 緢 括}

（1）強力人綟を試料として，X線法により酸加水分解初期に 起る結晶化の過程を明らかにし，それが格子歪みを有する不完全
結晶領域，すなわち中間領域の配列によるものであると説明した。

（2）種々の䋐維について, 酸加水分解初期に起る結晶化のよ うすを同様にX線法により研究し，ラミー，ベンベルグでは中間 領域が存在せず，したがってほとんど結晶化が起らないこと，お よびビスコース人綟，マーセル化ラミーでは, 多くの格子の乱れ た領域が存在するために著しい結晶化が起ることを確かめた。

（3）酸加水分解扣よびアルカリ浸清による䋐維の微細構造の 変化を研究し, ビスコース人絹 3 試料について, 少量のセルロー スIが残存していることを見出し，ビスコースの分散状態として セルロースI の格子を持つミセル分散の存在しうることを確かめ た。

\section{アクリルニトリルの重合におけるメタクリル酸の作用†}

(昭 和 31 年 4 月 27 日受理)

内田盛也・山口晃雄 - 長尾英夫*

\section{I. 緒言}

アクリルニトリルとメタクリル酸との共重合は，ともに水溶性 の単量体であるから水溶液重合を行うことができる。ところがア クリルニトリルの組成が多いと重合体は水に不溶性のために分離 して来る。

アクリルニトリルの水溶液重合については,すでに単量体の重 合体への吸着が重要な役割を示すことを報告したが1)，アクリル ニトリルとメタクリル酸との共重合に関しては Alfrey Jr. ら²) によって研究がなされ, 主として未解離の酸と解離して陰イオン になった場合の相対反応性の相違を指摘している。本報告はアク リルニトリル成分の多い不均一系の重合に抢けるメタクリル酸の 共存作用について，知見をうる目的で実験を行ったものである。

\section{II. 実 験 方 法}

（1）モノマー アクリルニトリル（AN) は，アメリカン・ シアナミド社（エチレンシアンヒドリン法）製品を常法により精 彆し,メタクリル酸 (MAA) は市販品を隇圧蒸留 $\left(71 \sim 72^{\circ} \mathrm{C} / 20\right.$ $\mathrm{mmHg}$ ) した後, 約 $2^{\circ} \mathrm{C}$ の冷蔵庫内に放置し, 析出した結晶を 採取して使用した。

（2）重合方法 $50 \mathrm{cc}$ 試験管に単量体を $0.4 \mathrm{~g}$, 水をその 18 倍量, 過硫酸カリ (K.P.S) $0.75 \%$, 酸性垔硫酸ソーダ $0.75 \%$ (各対モノマー $\mathrm{wt} \%$ ) 仕込み, 密栓した後 $35^{\circ} \mathrm{C}$ の恒温槽中に 浸漬静置して重合させた。塊状重合の場合には, 試験管中にモ， マー $8 \mathrm{~g}$ ，過酸化ベンゾイル（BPO） $1 \%$ （対モノマー wt \% ) を 仕込み，窒素ガスで置換した後，空間容量を約 $4 \mathrm{cc}$ になるよう に封管し, ついで $60^{\circ} \mathrm{C}$ の恒温槽に浸清静置して重合を行った。 いずれの場合でも試験管 6 本を 1 組とし，所要時間ごとに恒温槽

$\dagger$ 本報告を「アクリルニトリル重合体に関する研究（第 6 報)」とする.

* 帝国人造絹系 K K 研究所：岩国甫今津.

1) 長尾, 内田, 山口, 59, 695 (1956).

2) T. Alfrey Jr., C. G. Overberger, S. H. Pinner, J. Am. Chem. Soc. 75, 422 (1953).
より 1 本ずつ取出し，寒剤中に入れて冷却し，重合を停止させた 後栓を開き，あるいは封管を破り，約 $2.5 \%$ (対仕込モノマー wt \% ) のヒドロキノンを溶解した $500 \mathrm{cc}$ の水中に投入して十分 かきませて分散させた後, 温度を上げて吸着しているモノマーを 十分追出し, 重合体を沈殿させた後, 水洗, 乾燥して科量し, 重 合率, 組成および $\eta_{\mathrm{sp}} / C$ を決定した。組成はヶールダール法によ る窒素分析によって決定した。また $\eta_{\mathrm{p}} / C$ は $2 \mathrm{~g} / l$ ジメチルホル ムアミド溶液 $25^{\circ} \mathrm{C}$ の測定值である。

\section{III. 実験結果および考察}

AN と MAA との水溶液中での共重合を，モノマー組成が AN 100，95，90，85，80 wt\% のbのについて行った。

重合速度曲線を第 1 図に, 重合過程中に拈ける組成の变化と粘 度の変化をそれぞれ第 2 図と第 3 図に示す。また塊状重合の場合 の重合過程中に拈ける組成の変化と粘度の変化をそれぞれ第 4 図 と第 5 図に示す。第 1 図に見られるよ5にモノマー組成が MAA が多くなるにつれて重合速度は次第に低下し, MAA が Retarder として作用している。酢酸ビニルの乳化重合において，AN は Inhibitor としての作用を呈じ)，アクリル酸と $\mathrm{AN}$ との水溶夜

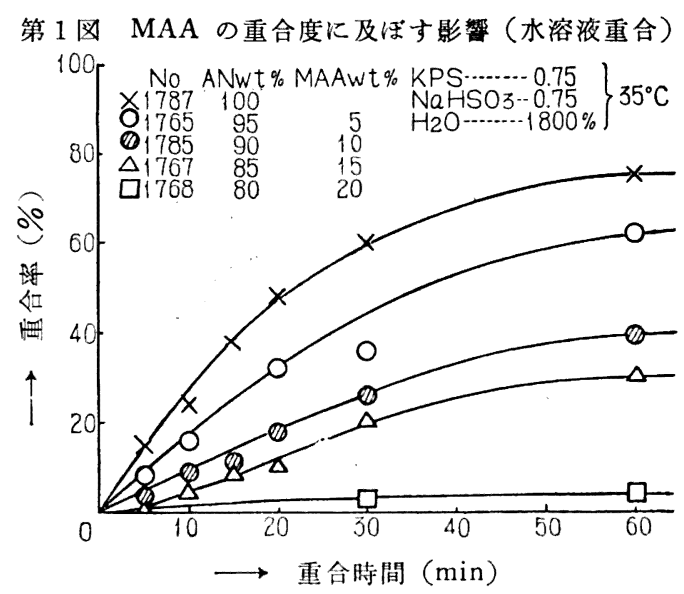

